\title{
ОСОБЛИВОСТІ ЗАСТОСУВАННЯ ОСВІТНІХ ТЕХНОЛОГІЙ У ФОРМУВАННІ МОБІЛЬНОСТІ СТУДЕНТІВ
}

\author{
Тернопільська В. І., Бакуліна О. С.
}

\section{ВСТУП}

Поступальний розвиток українського суспільства, процеси глобалізації, інтеграції України у європейську спільноту зумовили нові виклики щодо професійної підготовки майбутніх фахівців, підвищення рівня їхньої мобільності. Проблема формування мобільності майбутніх фахівців нині $€$ надзвичайно актуальною, що пояснюється суперечностями між тенденціями розвитку сучасного інформаційного суспільства та готовністю особистості прийняти нові форми соціальної поведінки, зокрема здатністю фахівця переключатися на іншу діяльність у зв'язку зі змінами кон'юнктури ринку праці, технологій виробництва, освоювати професії, які мають загальнопрофесійний характер, готовністю до оперативного відбору і реалізації оптимальних способів виконання професійних завдань. Звідси випливає, що складовою частиною професійної компетентності фахівця виступає його готовність до змін, мобільність.

Варто зазначити, що Закон України «Про вищу освіту» ставить перед університетською спільнотою нашої країни виклики щодо запровадження освітніх інновацій. Однією 3 таких інновацій є студентоцентроване навчання, в основу якого покладено компетентісний підхід до побудови та реалізації освітніх програм, повна інтеграція Національних рамок кваліфікацій, Нової структури вищої освіти, стандартів нового покоління, навчальних програм та окремих навчальних дисциплін ${ }^{1}$, формування у студентів універсальних навичок діяльності, що забезпечують розвиток мобільності як якісної характеристики особистості, орієнтацію на інноваційну діяльність.

Успішне формування мобільності студентської молоді відбувається за умови використання в освітньому процесі, поряд із традиційними, нових активних форм i методів навчання, в основі яких компетентісний підхід до підготовки майбутніх фахівців. Він грунтується на системі принципів, що ставлять викладача у суб'єктсуб'єктну позицію. Серед них - спрямованість на розвиток творчої

\footnotetext{
${ }^{1}$ Рашкевич Ю.М. Болонський процес та нова парадигма вищої освіти. Львівська політехніка, 2014. С. 51.
} 
особистості; індивідуалізація та диференціація; мобільність і динамічність; актуальність змісту теоретичної та практичної підготовки студентів; комплексність і всебічність змісту; його практична спрямованість; пріоритетність нетрадиційних активних форм, методів і засобів навчання.

Мобільність розглядаємо як інтегровану якість майбутнього фахівця, що формується в освітньому процесі закладу вищої освіти й поєднує в собі: усвідомлену потребу у фахових знаннях; мотивацію до професійного зростання; професійні знання та вміння, володіння способами професійної практичної діяльності; здатність до самоконтролю і самооцінки; готовність застосовувати знання й уміння для вирішення практичних завдань професійного характеру. 3 огляду на це формування мобільності студентів має відбуватися через застосування в освітньому процесі закладу вищої освіти традиційних та інноваційних технологій навчання.

\section{1. Мобільність особистості як наукова проблема}

Мобільність як наукове явище досліджували вчені, котрі розглядали природу мобільності: соціальну, психологічну, академічну, професійну та ін. Зокрема, П. Сорокін ${ }^{2}$ під соціальною мобільністю розуміє перехід індивіда або соціального об'єкта 3 однієї соціальної позиції у соціальному просторі в іншу. Вчений виділяє два основні типи соціальної мобільності: горизонтальну та вертикальну. Горизонтальна соціальна мобільність передбачає перехід соціального об'єкта 3 однієї соціальної групи в іншу, розташовану на тому самому рівні. До прикладу, 3 одного громадянства в інше, 3 однієї родини в іншу, з однієї організації в іншу тощо. Вертикальна соціальна мобільність включає взаємини, що виникають у процесі переміщення індивіда 3 одного соціального прошарку в інший ${ }^{3}$.

На мобільності як професійному, соціальному, галузевому, територіальному переміщеннях індивідів, яке є своєрідною формою їхньої адаптації до нових технологічних i економічних умов функціонування, наголошує Т. Заславська. Серед чинників, що стимулюють розвиток мобільності індивіда, вчена виділяє фактори розвитку ринкових відносин, які забезпечують досягнення якісно нового рівня мобільності та професійно-практичної підготовки конкурентоспроможного фахівця. У понятті «професійна мобільність» необхідно розрізняти два аспекти: об’єктивний i суб'єктивний.

Сорокин П. Человек. Цивилизация. Общество / под общ. ред. А.Ю. Согомонова. Москва : Политиздат, 1992. 543 с.

${ }^{3}$ Сорокин П.А. Социальная мобильность, ее формы и флуктуации. Социология : хрестоматия для вузов. Москва : Академ. Проект ; Екатеринбург : Деловая книга, 2002. C. 449-479. 
Об'єктивний, на іiї думку, базується на науково-технічних і соціальноекономічних передумовах, включаючи сам процес зміни професії. Суб'єктивний розкриває процес зміни інтересів працівників та акт прийняття рішення щодо зміни місця роботи чи професії, що залежить від таких індивідуальних характеристик людей, як потреби, ціннісні орієнтації, моральні якості та інші визначальні мотиви ${ }^{4}$.

У працях вчених сутність професійної мобільності визначається як: якість особистості, яка забезпечує внутрішній механізм розвитку людини; діяльність людини, детермінована подіями; середовище, результатом якого виступає самореалізація людини у професії та житті; процес перетворення людиною самої себе та навколишнього професійного й життєвого середовища ${ }^{5}$. Об'єктивною основою мобільності окремого працівника або групи $\epsilon$ зміни у змісті та характері праці (предметі, методах, цілях).

Варто зазначити, що проблема мобільності на особистісному рівні тісно пов'язана зі змінами характеру самовизначення особистості та появою нових професій, старінням тих професій, що з'явилися раніше Загалом ідеться про мобільність як сукупність особистісних характеристик і особливих форм поведінки, які виявляються в ситуації зміни професії: схильності до творчості, прагнення до постійного самовдосконалення та самоактуалізації, здатності до ризику, прояву ініціативи, заповзятливості у суспільному та громадському житті, на робочому місці тощо.

Як стверджує С. Рубінштейн ${ }^{7}$, в особистості, котра усвідомила свій шлях, вибудовується «генеральна лінія життя», представлена єдністю мотивів і кінцевої мети. На думку вченого, ця «генеральна лінія»

4 Заславская Т.И. Трудовая мобильность как предмет экономикосоциологического исследования. Методологические проблемы сочиологического исследования мобильности трудовых ресурсов / Сиб. отд-ние. Ин-т экон. И организации промышл. производства. Новосибирск : Наука, 1974. 318 с.

5 Іванченко Є.А. Формування професійної мобільності майбутніх економістів у процесі навчання у вищих навчальних закладах : дис. ... канд. пед. наук : 13.00.04. Одеса, 2005. $181 \mathrm{c.}$

6 Дворецкая Ю.Ю. Личностные особенности специалистов с разным уровнем профессиональной мобильности. Человек. Сообщество. Управление: взгляд молодого исследователя. 2007. С. 31-37; Неделько Е.Г. Формирование мотивационной готовности к профессиональной мобильности у студентов ВУЗ : дис. ... канд. пед. наук : 13.00.08 Магнитогорск, 2007. 156 с.; Тернопільська В.І., Чижова Н.В. Мобільність особистості як предмет наукового дослідження. Теоретико-методичні проблеми виховання дітей та учнівської молоді. 2016. № 20. C. 234-243.; Santiago P., Tremblay K., Basri E., Arnal E. Tertiary Education for the Knowledge Society. Social Features, Equity, Innovation, Labour Market, Internationalisation. 2008. Vol. 2. P. 243.

${ }^{7}$ Рубинштейн С.Л. Основы общей психологии. Санкт-Петербург : Питер, 2002. 
є динамічною $\mathrm{i}$ може змінюватися залежно від обставин і трансформаційних процесів у самій особистості.

Водночас за сучасних трансформаційних умов індивід постійно перебуває у ситуації невизначеності, пошуку, самоосвіти та самовдосконалення. Люди, які «не встигли перебудуватися», зазвичай опиняються на узбіччі життя ${ }^{8}$. Виявлення мобільності людини за сучасних соціально-економічних умов можливе лише у разі формування в неї такої «картини світу, у якій потрапляння людини в ситуацію невизначеності <...> відсутності відповідей на багато питань - норма, а не аномалія соціального життя» ${ }^{9}$.

У цьому аспекті Р. Пріма розглядає професійну мобільність як «підгрунтя ефективного реагування особистості на «виклик» сучасного суспільства, своєрідний особистісний ресурс, що лежить в основі дієвого перетворення суспільного довкілля і самого себе в ньому; системне багатогранне явище, яке вимагає інтегрованого, міждисциплінарного підходу до дослідження; внутрішній (мотиваційний, інтелектуальний, вольовий) потенціал особистості, що лежить в основі гнучкої орієнтації та діяльнісного реагування за динамічних соціальних і професійних умов відповідно до власних життєвих позицій; забезпечує готовність до змін і реалізацію цієї готовності у своїй життєдіяльності (готовність особистості до сучасного життя 3 його багатоаспектними чинниками вибору); детермінує професійну активність, суб'єктність, творче ставлення до професійної діяльності, особистісного розвитку, що сприяє ефективному розв'язанню фахових проблем» ${ }^{10}$. Професійна мобільність $\epsilon$ інтегративною характеристикою особистості та детермінована подіями, які змінюють середовище, результатом самореалізації особистості у професії й житті, а також перетворення нею самої себе й навколишнього світу.

Вчені також наголошують на мобільності як комплексі особистісних якостей і здібностей особистості: соціальної активності, що виражається у готовності брати участь у різноманітних громадських заходах, проєктах різної змістової спрямованості; діяльного інтересу до різних сфер соціальної та професійної активності; високої адаптивності до різних соціальних ситуацій, функціонально різних видів діяльності; креативності, інноваційності, налаштованості на творче ставлення до будь-якої справи, творчого перетворення будь-якої ситуації ${ }^{11}$.

${ }^{8}$ Нєлєпова А.В. Методика формування інформаційної мобільності майбутніх агрономів-дослідників : автореф. дис. ... канд. пед. наук : 13.00.02. Київ, 2011. 22 с.

9 Абульханова-Славская К.А., Березина Т.Н. Время личности и время жизни. Санкт-Петербург : Алтейя, 2001. С. 3.

10 Пріма Р.М. Формування професійної мобільності майбутнього вчителя початкових класів: теорія і практика : монографія. Донецьк : ІМА-прес, 2009. С. 101-102.

11 Лапина О.А., Никитина Е. А. Профессиональная мобильность как интегративное качество педагога : монография. Иркутск : ИГЛУ, 2012. С. 44. 
Виходячи зі специфіки економічної складової частини мобільності, зазначимо, що вона пов'язана із розглядом іiі як елемента ринкової організації праці, а саме: відтворенням трудових ресурсів, зміною професійного i кваліфікаційного статусу робітників як виробників i споживачів матеріальних благ ${ }^{12}$. У цьому аспекті наголошуємо на мобільності, яка слугує механізмом чергування та поєднання різних видів діяльності особистості, оскільки соціально-економічні відносини у країні, розвиток науки й техніки впливають на професійні групи та викликають рух, що руйнує їхню однорідність. Як зміна професії, мобільність $€$ одним із головних показників закону зміни праці. У відповідних проявах виникають нові напрями професійної діяльності, які потребують перекваліфікації ${ }^{13}$. Безперечно, такий контекст актуалізує проблему формування мобільності майбутніх фахівців.

\section{2. Технологічне забезпечення формування мобільності студентів}

Встановлено, що у межах педагогічної науки розглядають інноваційні форми, методи, засоби навчання та традиційні (пояснювальноілюстративні, проблемні, програмовано-диференційовані та поєднання вищеназваних). Водночас окреслений педагогічний інструментарій не сприяє розвитку мислення, логічних і творчих умінь студентів.

Характерними особливостями сучасних інноваційних технологій $\epsilon$ відмова від усталених штампів, стереотипів у навчанні, вихованні та розвитку особистості студента. Безперечно, такий підхід сприяс їх широкому впровадженню у зв'язку зі зміною освітньої парадигми зі знаннєвої на результативну й активним розвитком компетентнісної моделі освіти. Упровадження інновацій у формування мобільності майбутніх фахівців відбувається через інтерактивні методи навчання, які передбачають певну логіку i послідовність навчальної діяльності: мотивацію, формування нового досвіду, його усвідомлення через застосування, рефлексію.

У цьому аспекті науковці серед інноваційних технологій навчання виокремлюють такі види: інформаційні - спрямовані на розвиток знань, умінь, навичок; операційні - формують способи розумових дій; технології саморозвитку - формують самокеровані механізми особистості; евристичні - розвивають творчі здібності; прикладні розбудовують дієво-практичну сферу ${ }^{14}$.

12 Іванченко Є.А. Формування професійної мобільності майбутніх економістів у процесі навчання у вищих навчальних закладах : дис. ... канд. пед. наук : 13.00.04. Одеса, 2005. С. 18-19.

${ }^{13}$ Сушенцева Л.Л. Формування професійної мобільності майбутніх кваліфікованих робітників у професійно-технічних навчальних закладах: теорія і практика : монографія / за ред. Н.Г. Ничкало. Кривий Ріг : Видавничий дім, 2011. 439 с.

14 Муц Л.Б. Застосування педагогічних програмних засобів освіти у навчальному процесі вищої школи. Медична освіта. 2013. № 1. С. 42-46. 
Причому формування у студентів мобільності можливе за умови послідовного та постійного впровадження інноваційних форм, методів в освітній процес і використання їхнього розвивального потенціалу у навчанні. Зокрема, у діловій грі, на тренінгу чи у процесі аналізу професійних ситуацій готові знання не даються, студентів спонукають до такої діяльності, яка вимагає самостійного пошуку інформації різноманітними ігротехнічними та творчими засобами. Тим самим створюються умови для їхньої ініціативи та творчого пошуку ефективних рішень конкретних завдань i ситуацій. Власний практичний досвід студентів $є$ лише передумовою для початку пошуку нової інформації, умовою для аналізу й отримання інших результатів, діагностика і прогнозування яких дозволяють вдосконалити наявний досвід. У свою чергу, за умови продуманого та професійно грамотного використання цих форм, методів, засобів в освітньому процесі можливе формування у них мобільності, готовності до інноваційної фахової діяльності в майбутньому.

Відзначимо, що традиційні форми, методи навчання орієнтуються переважно на викладача, де він - суб'єкт навчання освітнього процесу, а студенти - об'єкти його педагогічних впливів. Ефективність навчання залежить від форм, методів і прийомів діяльності викладача (основну увагу приділяють пошуку й обгрунтуванню ефективних методів викладання), а пізнавальної активності студентів зазвичай не враховують. Традиційні форми та методи навчання більшою або меншою мірою $є$ різновидами репродуктивного навчання, де роль викладача є провідною.

Так, традиційну дидактичну систему обгрунтовано Ф. Гербартом ${ }^{15}$. Ця система орієнтована на домінування викладача в освітньому процесі. Педагог визначив чотири формальні ступені навчання: зрозумілість, асоціацію, узагальнення, застосування. Зрозумілість передбачає викладення нового матеріалу у формі розповіді чи бесіди. Цьому має передувати підготовка студентів, актуалізація опорних знань. Викладачу необхідно зрозуміло, чітко, доступно подати матеріал iз використанням наочності, сформувати у студентів конкретні уявлення. Асоціація презентується через забезпечення зв'язку нового матеріалу 3 раніше засвоєними знаннями, формування у студентів понять, висновків, узагальнень на основі раніше набутих уявлень. Узагальнення відбувається у процесі включення нових понять до раніше сформованої системи знань методами бесіди та дискусії. Застосування набутих знань на практиці відбувається за допомогою вправ і завдань, унаслідок виконання яких у студентів формуються вміння. Логіка навчання полягає у послідовності таких дій: пояснення,

${ }^{15}$ Umriß pädagogischer Vorlesungen Verfasserang / Johann Friedrich Herbart. Besorgt von Eva Matthes; Carsten Heinze Ort Darmstadt Verlag Wiss. Buchges., 2003. 168 p. 
осмислення, узагальнення й використання на практиці. Водночас ця система не сприяє активізації розумових дій майбутніх фахівців, пригнічує їхню самостійність, ініціативність і творчість у процесі професійної підготовки, формування мобільності.

Отже, застосування традиційних форм, методів навчання передбачає: подачу інформації викладачем $\rightarrow$ сприйняття, осмислення, конспектування, заучування інформації студентом $\rightarrow$ відтворення завченої інформації для контролю й оцінювання викладачем. У традиційних формах навчання значна увага приділяється засвоєнню загальнонаукових, професійних і спеціальних знань, умінь і навичок. Зазначимо, що в межах застосування традиційних форм і методів навчання пізнавальна діяльність має репродуктивний характер: викладач передає студентам готові знання, використовуючи пояснення, доведення, аргументи із застосуванням різноманітних засобів наочності. Характерними особливостями такого навчання є повідомлення готових знань, пояснення, обгрунтування. Однак традиційні форми та методи навчання мають і позитивні аспекти. Зокрема, вони забезпечують швидке, міцне засвоєння майбутнім фахівцем навчальної інформації й оволодіння способами практичної діяльності. Позитивною стороною такого навчання $\epsilon$ його систематичність, поетапність. Застосування традиційних форм, методів навчання є ефективним, коли у студентів не сформовані опорні знання для вирішення практичних ситуацій.

У свою чергу, негативними характеристиками традиційних форм і методів $\epsilon$ недостатній рівень реалізації розвиваючої функції навчання, переважно репродуктивна діяльність майбутнього фахівця. Таке навчання не передбачає самостійного пошуку знань, не сприяє розвитку творчого мислення, здатності самостійно вирішувати проблеми професійного характеру 3 елементами мобільності, не враховує індивідуальні особливості студентів.

Отже, застосування традиційних форм і методів навчання у процесі формування мобільності студентів сприяє засвоєнню ними знань у вигляді фактологічного матеріалу й понятійного апарату; формування професійних умінь здійснюється на репродуктивному рівні. У подачі навчального матеріалу провідна роль належить викладачеві.

У контексті інноваційних підходів до навчання, на думку М. Кларіна ${ }^{16}$, ї можна розподілити на два типи:

1) інновації-модернізації, які модернізують навчальний процес і спрямовані на досягнення гарантованих результатів у межах його традиційної репродуктивної орієнтації;

\footnotetext{
${ }^{16}$ Кларин М.В. Инновации в обучении: метафоры и модели: анализ зарубежного опыта. Москва : Наука, 1997. 223 с.
} 
2) інновації-трансформації, що перетворюють традиційний навчальний процес $\mathrm{i}$ спрямовані на забезпечення його дослідницького характеру, організацію пошукової навчально-пізнавальної діяльності студента.

Як бачимо, принципова відмінність цих підходів полягає у ролі тих, хто навчається (студентів), у реалізації їхної навчальної діяльності, оскільки за умови традиційного підходу вони залишаються пасивними «споживачами» навчальної інформації, що подається, навчання здійснюється на репродуктивному рівні.

На нашу думку, упровадження інноваційних форм і методів також спрямоване на вдосконалення активного процесу засвоєння студентом знань, умінь, розвиток їхнього творчого потенціалу, самостійної дослідницької діяльності. Отже, пошук нових інноваційних форм і методів навчання та впровадження їх в освітній процес закладів вищої освіти сприятиме забезпеченню високого рівня професійної підготовки майбутніх фахівців, формуванню у них мобільності.

Слід зазначити, що структуру і зміст інноваційних форм, методів формування мобільності студентів проєктують з урахуванням того, що ефективність освітнього процесу у закладі вищої освіти залежить і від рівня кваліфікації викладачів, їхніх ціннісних орієнтацій.

Бачиться особливо суттєвим у процесі формування мобільності майбутніх фахівців урахування критеріїв ефективності результатів їхнього професійного навчання, зокрема глибини знань, що характеризується кількістю усвідомлених суттєвих зв'язків одного знання 3 іншим, які співвідносяться; дієвість знань, що визначає готовність та уміння студентів використовувати їх у типових і проблемних ситуаціях професійного характеру; системність, яка визначається як система усвідомлення знань майбутніми фахівцями, що полягає в розумінні зв'язків між ними, шляхів отримання знань, умінь їх використовувати. Розвиток у студентів означених критеріїв корелює зі сформованістю у них мобільності.

Формування мобільності майбутніх фахівців здійснюється із як використанням традиційних форм організації навчання (лекцій, семінарів, самостійної (індивідуальної) роботи студентів), так i інноваційних (лекцій-презентацій, інтерактивних лекцій, лекційдискусій, проєктної діяльності, роботи з електронною бібліотекою). Освітній процес потребує таких методів навчання, які сприяли би формуванню та виявленню мобільності майбутніх фахівців залежно від їхніх особистісних схильностей та інтересів. До них можна віднести зустрічі з провідними фахівцями галузі, метод проєктів, створення особистісних портфоліо, case-studies, інтерактивні методи навчання та ін.

Ефективним у формуванні мобільності студентів визначаємо метод аналізу конкретної ситуації (case-study). Це педагогічна технологія, заснована на моделюванні професійної ситуації 3 метою аналізу 
певного випадку, виявлення проблеми, мобільного пошуку альтернативних рішень i прийняття оптимального вирішення проблеми відповідно до професійної спеціалізації.

Варто зауважити, що кейс-метод сприяє формуванню у майбутніх фахівців мобільності, умінь застосовувати отримані професійні знання у вирішенні практичних ситуацій. У процесі використання кейс-методу здійснюється формування проблеми та способів іії вирішення на основі пакету матеріалів (кейса) з описом ситуації з різних джерел: наукової, спеціальної літератури, науково-популярних журналів та ін. У кейсі міститься неоднозначна інформація з певної проблеми. Кейс одночасно $\epsilon$ i завданням, і джерелом інформації для усвідомлення студентами варіантів ефективних дій ${ }^{17}$.

Алгоритм мобільного вирішення й аналізу проблемного кейс-стаді:

1) прочитати інформацію, щоб скласти цілісне уявлення про ситуацію (рекомендовано спочатку не аналізувати ситуацію);

2) повторно уважно ознайомитися 3 інформацією, виділити найбільш важливі елементи;

3) розділити інформацію на окремі елементи та схарактеризувати ситуацію (визначити зміст проблеми та факти);

4) ознайомитися 3 літературою 3 цієї проблеми, сформулювати критерії для перевірки правильності вирішення проблеми;

5) виробити альтернативні варіанти вирішення, якщо такі можливі;

6) розробити перелік практичних ситуацій щодо реалізації вирішення типової професійної ситуації.

Зазначимо, що кейс-метод методологічно значно відрізняється від традиційного змісту навчання в контексті застосування дидактичних принципів. Так, застосування кейс-методу передбачає врахування таких дидактичних принципів, як: збір та обробка інформації про кожного студента ще до початку проведення занять, тобто індивідуальний підхід до кожного; забезпечення студентів у процесі проведення занять достатнім обсягом наочного матеріалу (відео-, аудіокасетами, друкованими статтями, монографіями, підручниками, навчальними посібниками, доступом до мережі Internet та ін.); надання у процесі навчання свободи у власному виборі дисциплін, форм навчання, завдань, способів іх виконання; спільна активна робота студентів і викладача, підтримка з боку викладача; основна увага приділяється розвитку сильних сторін студента;

Кейс-метод відрізняється від інших методів навчання за такими ознаками та технологічними особливостями: включає в себе аналітичні процедури, різні операції дослідницького характеру, тобто

17 Тернопольская В.И., Бакулина О.С. Особенности формирования профессиональной компетентности будущих специалистов по налогообложению и таможенному делу. International scientific journal “Progress”. 2018. № 1-2. P. 94-97. 
$\epsilon$ специфічним різновидом дослідно-аналітичної технології; розглядається як технологія групового навчання на основі взаємного обміну інформацією; виступає синергетичною технологією на основі занурення групи у ситуацію, збільшення своїх знань та обміну відкриттями; об'єднує в єдине технології розвивального навчання, які містять індивідуальний, груповий розвиток і формування особистісних якостей особистості, зокрема мобільності; проявляється як специфічний різновид проєктної технології; розглядається як технологія «створення успіху», включає діяльність нарощування пізнавальної активності студентів, стимулювання їхнього успіху та підтримки їхніх досягнень ${ }^{18}$. Важливою характеристикою кейс-методу $\epsilon$ його ефективна інтеграція з іншими методами навчання.

У педагогічній літературі існують різні підходи до класифікації кейсів. Зокрема, за ступенем реальності кейси поділяють на «польові» (засновані на фактах із реального життя) i «крісельні» (засновані на вигадці авторів). За обсягом: «американські» (довгі) та «західноєвропейські» (короткі). За встановленими цілями: ілюстративні й навчальні кейси. На думку багатьох вчених, кейси бувають «мертві» (вміщують всю необхідну для аналізу інформацію) i «живі» (провокують студентів до пошуку додаткової інформації для аналізу) ${ }^{19}$.

Встановлено, що кейси класифікують залежно від організації презентованого в них матеріалу та дидактичних цілей. Зокрема, зовнішньоорганізаційні кейси переважно орієнтовані на аналіз і з'ясування стану зовнішнього середовища, тому в них докладно описуються проблеми навколо організації (екології, законів, реформ тощо). Ці кейси легко відрізнити від інших за відсутністю матеріалів про саму організацію. Джерелами кейса $\epsilon$ «бібліотечні» матеріали із журналів, звітів. У внутрішньоорганізаційних кейсах наголос робиться на фактах і подіях всередині організації. Такі кейси використовуються для вивчення організаційно-управлінських проблем і «людських» взаємин.

Так, кейси вирішення навчальних проблем і прийняття рішень передбачають, що рішення має бути сформульоване на основі недостатньої (або надлишкової) інформації, фактів, даних і подій, описаних у кейсах. Важливо, щоб змістовно матеріал у таких кейсах презентував ознаки організаційної конфліктності, багатоваріантності методів прийняття рішень, альтернативності самих рішень, суб’єктивності рольової поведінки, динаміки подій і можливостей реалізації запропонованого рішення.

18 Долгоруков А. Метод case-study как современная технология профессионально-ориентированного обучения. URL: http://www.vshu.ru/lections.php? tab_id=3\&a=info\&id=2600 (дата звернення: 18.09.2020).

${ }_{19}$ Манчестерський університет. URL: http://www.manchester.ac.uk (дата звернення: 21.04.2020). 
Загалом найбільш поширеними у навчальній діяльності $\epsilon$ ілюстративні кейси, оскільки їх легко знайти у пресі серед статей, книжок, відеокліпів, науково-популярних, художніх фільмів. На заняттях такі кейси часто виступають у формі «in-basket», інциденту, і вступних ілюстрацій до проблеми, котра викладається на занятті. Ілюстративні кейси $є$ короткими по тексту (від одного абзацу до декількох сторінок) і майже не містять зайвої інформації. Вони також зручні для тестів, міні- і бліц-контрольних.

За ступенем впливу основних джерел кейса на характер і види діяльності студентів виділяють:

1) практичні кейси, які відображають абсолютно реальні життєві ситуації та формують конкретні практичні вміння і навички. Основне завдання практичного кейса полягає в тому, щоб детально і докладно відобразити життєву ситуацію. Кейс створює практичну, діючу модель ситуації. Навчальне призначення такого кейса може зводитися до тренінгу студентів, закріплення знань, умінь і навичок їхньої поведінки (прийняття рішень) у ситуації. Такі кейси повинні бути максимально наочними та детальними;

2) навчальні кейси, основним завданням яких виступає навчання тих чи інших узагальнених прийомів діяльності, формування ключових компетенцій студентів. Навчальний кейс відображає типові професійні ситуації, з якими доведеться зіткнутися фахівцю у процесі його діяльності;

3) дослідні кейси, орієнтовані на здійснення пошукової, науководослідницької, експериментальної діяльності. Їхній основний зміст полягає в тому, що вони виступають моделлю для отримання нового знання про ситуацію й поведінку в ній. Застосовувати його краще не як метод первинного професійного навчання, а у процесі підвищення кваліфікації та перепідготовки фахівців.

Залежно від мети розрізняють:

- ілюстративні навчальні кейси, мета яких - на прикладі навчити студентів алгоритму прийняття правильного рішення в певній ситуації;

- навчальні кейси з формулюванням проблеми, в яких описується ситуація в конкретний період часу; метою такого кейса є діагностування ситуації та самостійне прийняття рішення щодо зазначеної проблеми;

- навчальні кейси без формулюванням проблеми, у яких описується більш складна, ніж у попередньому варіанті, ситуація, де проблема чітко не виявлена, а представлена у статистичних даних, оцінках суспільної думки. Метою такого кейса $\epsilon$ самостійне виявлення проблеми й альтернативних шляхів іiї вирішення 3 аналізом наявних ресурсів $^{20}$.

${ }^{20}$ Козырева Л.Н. Метод кейс-стади и его применение в процессе обучения студентов-социономов. Официальный сайт Сев.-Зап. акад. и гос. службы. Сев.-Зап. акад. госслужбы. 2007. URL: www.nwags.ru/files/files/407324 (дата обращения: 21.04.2020). 
Кейси можуть бути запропоновані студентам у друкованому, відео-, аудіо-, мультимедіа або комбінованих видах. Отже, кейс може як включати відомі академічні моделі, так і не відповідати жодній із них.

Робота над кейсом орієнтує майбутніх фахівців на опанування комплексу знань і умінь роботи з контентом професійного проблемного поля; вироблення стандартів поведінки та відповідного самоконтролю; чітке розуміння наслідків прийнятих рішень; виявлення відповідальності, внутрішньої мотивації на професійне зростання, формування мобільності.

Водночас кейс-метод не може замінити традиційні методи навчання, адже витрачання усього навчального часу на розбір конкретних ситуацій може призвести до формування у студентів стереотипного, упередженого підходу до вирішення проблем.

Аналіз наукових досліджень показав, що проблема формування мобільності майбутніх фахівців $\epsilon$ актуальною і своєчасною та зумовлена модернізацією професійної освіти відповідно до вимог європейського освітнього простору. Зазначимо, що інтерактивні технології навчання включають у себе чітко спланований очікуваний результат навчання, окремі інтерактивні методи та прийоми, що стимулюють процес пізнання студентів і сприяють досягненню запланованих результатів. На відміну від методик, інтерактивні навчальні технології не обираються для виконання певних навчальних завдань, а самою своєю структурою визначають кінцевий результат. До того ж кожен із методів потребує від студента чіткої покрокової, поетапної реалізації з обов'язковим прогнозуванням результатів навчання.

Інтерактивні технології застосовуються у різних формах навчальної діяльності (нових і традиційних), які можуть знайти своє місце у процесі професійної підготовки майбутніх фахівців: лекціяхконференціях, проблемних лекціях, семінарських заняттях, практичних заняттях, майстер-класах, круглих столах, групових тренінгах, самостійній та індивідуальній роботах, практиці.

Серед ефективних засобів навчання виокремлюємо також навчальні посібники, автентичний матеріал, роздатковий матеріал, технічні засоби навчання: комп'ютери (наприклад, для унаочнення розроблених майбутніми фахівцями проєктів застосовували мультимедійні презентації, створені за допомогою комп'ютерної програми Microsoft PowerPoint), мережу Інтернет (аудіо-/відеоматеріали, новини, сайти відомих фахових журналів і бюлетенів, розміщені у вільному доступі), що відповідають сучасним вимогам до засобів навчання в освітньому процесі закладу вищої освіти.

Наголосимо на мозковому штурмі як інтерактивному методі, який заохочує студентів виявляти мобільність, пропонувати ідеї, рекомендації, пропозиції завдяки відсутності критичних зауважень із боку викладача чи інших студентів на стадії генерації ідей. Цей метод 
застосовується для досягнення таких цілей: виявити всі можливі альтернативи, перш ніж приймати рішення; розглянути різноманітні аспекти питання, перш ніж спробувати його вирішити; активізувати групове обговорення ${ }^{21}$.

Відзначимо також рольову гру як активний метод навчання для розвитку мобільності, комунікативних умінь студента, за допомогою якого можна набути досвіду використання певних навичок в ігровій ситуації; проаналізувати альтернативні способи дій, ідеї, запропоновані для виконання завдання; відпрацювати окремі види рольової поведінки та застосувати їх у реальному житті; набути впевненості у своїх силах під час практичних дій, репетиції у процесі виконання зазначеної ролі ${ }^{22}$.

Особливою формою формування мобільності студентів є майстеркласи, які забезпечують обмін досвідом між «майстром» (запрошеним досвідченим фахівцем-практиком, котрий досягнув успіху у професійному житті) й учасниками. Доцільною формою роботи у розвитку умінь і навичок мобільності є круглі столи, що належать до різновиду ділової дискусії та проводяться 3 метою прийняття компромісних рішень. Для обговорення необхідно підбирати неоднозначні, проблемні теми, які містять інформацію про серйозні наслідки ситуацій i мають декілька альтернативних варіантів вирішення. Вони повинні бути короткі, інформативні, краще з реального життя. Під час таких засідань учасники висловлюють не загальну, а власну думку, що виробляє здатність до самостійного та ініціативного прийняття рішень.

\section{ВИСНОВКИ}

Таким чином, мобільність $€$ інтегрованою характеристикою особистості студента i виявляється у соціальній активності, відповідальності, інноваційних підходах до вирішення стандартних ситуацій, здатності адаптуватися до нових ситуацій особистісного та професійного змісту. Формування мобільності реалізується шляхом використання в освітньому процесі інноваційних і традиційних форм i методів навчання. До традиційних форм навчання відносимо: лекції, семінари, самостійну роботу студентів. Інноваційні форми формування мобільності студентів реалізуються через лекції-презентації, інтерактивні лекції, лекції-диспути, проєктну діяльність, case-study, майстер-класи, роботу з електронною бібліотекою та ін.

${ }^{21}$ Пєтухова Л.Є. Теоретичні основи підготовки вчителів початкових класів в умовах інформаційно-комунікаційного педагогічного середовища : монографія. Херсон : Айлант, 2007. 200 с.

22 Семиченко В.А. Пріоритети професійної підготовки: діяльнісний чи особистісний підхід? Неперервна освіта: проблеми, пошуки, перспективи : монографія / за ред. І. А. Зязюна. Київ : Віпол, 2000. С. 176-203. 
Встановлено, що саме застосування case-study як педагогічної технології грунтується на моделюванні професійної ситуації з метою аналізу певного випадку, виявлення проблеми, мобільного пошуку альтернативних рішень і прийняття оптимального вирішення проблеми відповідно до професійної спеціалізації. Кейс-метод сприяє формуванню у майбутніх фахівців мобільності, умінь застосовувати отримані професійні знання у вирішенні практичних ситуацій. Робота над кейсом орієнтує майбутніх фахівців на опанування комплексу знань і умінь роботи 3 контентом професійного проблемного поля; вироблення стандартів поведінки та відповідного самоконтролю; чітке розуміння наслідків прийнятих рішень; виявлення відповідальності, внутрішньої мотивації на професійне зростання, формування мобільності.

\section{АНОТАЦІЯ}

У статті проаналізовано теоретичні положення щодо формування мобільності студентів, розкрито поняття «мобільність», «інтерактивні форми та методи навчання». Окреслено поняття «мобільність студента» як інтегровану якість майбутнього фахівця, котра формується в освітньому процесі закладу вищої освіти й поєднує в собі: усвідомлену потребу у фахових знаннях; мотивацію до професійного зростання; професійні знання та вміння, володіння способами професійної практичної діяльності; здатність до самоконтролю i самооцінки; готовність застосовувати знання й уміння для вирішення практичних завдань професійного характеру. Зазначено, що пошук інноваційних форм і методів навчання та впровадження їх в освітній процес закладів вищої освіти сприятимуть забезпеченню високого рівня професійної підготовки майбутніх фахівців, формуванню у них мобільності. Виокремлено традиційні форми організації навчання (лекції, семінари, самостійну (індивідуальну) роботу студентів) та інноваційних (лекцію-презентацію, інтерактивні лекції, лекції-дискусії, проєктну діяльність, роботу з електронною бібліотекою). Розкрито напрями активізації мобільності студентів. Представлено форми та методи інтерактивного навчання в контексті формування мобільності майбутніх фахівців (лекції, ділові та рольові ігри, кейс-метод, диспут, дебати).

\section{ЛIТЕРАТУРА}

1. Абульханова-Славская К.А., Березина Т.Н. Время личности и время жизни. Санкт-Петербург : Алтейя, 2001. 304 с.

2. Дворецкая Ю.Ю. Личностные особенности специалистов с разным уровнем профессиональной мобильности. Человек. Сообщество. Управление: взгляд молодого исследователя. 2007. С. 31-37.

3. Долгоруков А. Метод case-study как современная технология профессионально-ориентированного обучения. URL: 
http://www.vshu.ru/lections.php?tab_id=3\&a=info\&id=2600 звернення: 18.09.2020).

4. Заславская Т.И. Трудовая мобильность как предмет экономикосоциологического исследования. Методологические проблемы социологического исследования мобильности трудовых ресурсов / Сиб. отд-ние. Ин-т экон. и организации промышл. производства. Новосибирск : Наука, 1974. 318 с.

5. Іванченко Є.А. Формування професійної мобільності майбутніх економістів у процесі навчання у вищих навчальних закладах : дис. ... канд. пед. наук : 13.00.04. Одеса, 2005. $181 \mathrm{c.}$

6. Кларин М.В. Инновации в обучении: метафоры и модели: анализ зарубежного опыта. Москва : Наука, 1997. 223 с.

7. Козырева Л.Н. Метод кейс-стади и его применение в процессе обучения студентов-социономов. Официальный сайт Сев.-Зап. акад. и гос. службы. Сев.-Зап. акад. госслужбы. 2007. URL: www.nwags.ru/files/files/407324 (дата звернення: 21.04.2020).

8. Лапина О.А., Никитина Е.А. Профессиональная мобильность как интегративное качество педагога : монография. Иркутск : ИГЛУ, 2012. $141 \mathrm{c}$.

9. Манчестерський університет. URL: http://www.manchester.ac.uk (дата звернення: 21.04.2020).

10. Муц Л.Б. Застосування педагогічних програмних засобів освіти у навчальному процесі вищої школи. Медична освіта. 2013. № 1. С. 42-46.

11.Неделько Е.Г. Формирование мотивационной готовности к профессиональной мобильности у студентов ВУЗ : дис. ... канд. пед. наук : 13.00.08. Магнитогорск, 2007. $156 \mathrm{c}$.

12. Нєлєпова А.В. Методика формування інформаційної мобільності майбутніх агрономів-дослідників : автореф. дис. ... канд. пед. наук : 13.00.02. Київ, 2011. 22 с.

13. Пєтухова Л.є. Теоретичні основи підготовки вчителів початкових класів в умовах інформаційно-комунікаційного педагогічного середовища : монографія. Херсон : Айлант, 2007. 200 с.

14. Пріма Р.М. Формування професійної мобільності майбутнього вчителя початкових класів: теорія і практика : монографія. Донецьк : IMA-прес, 2009. 367 с.

15. Рашкевич Ю.М. Болонський процес та нова парадигма вищої освіти. Львівська політехніка, 2014. 168 с.

16. Рубинштейн С.Л. Основы общей психологии. Санкт-Петербург : Питер, 2002. 720 с.

17. Сорокин П. Человек. Цивилизация. Общество / под общ. ред. А.Ю. Согомонова. Москва : Политиздат, 1992. 543 с.

18. Семиченко В.А. Пріоритети професійної підготовки: діяльнісний чи особистісний підхід? Неперервна освіта: проблеми, пошуки, перспективи : монографія / за ред. І.А. Зязюна. Київ : Віпол, 2000. С. 176-203. 
19. Сорокин П.А. Социальная мобильность, ее формы и флуктуации. Социология : хрестоматия для вузов. Москва : Академ. Проект ; Екатеринбург : Деловая книга, 2002. С. 449-479.

20. Сушенцева Л.Л. Формування професійної мобільності майбутніх кваліфікованих робітників у професійно-технічних навчальних закладах: теорія і практика : монографія / за ред. Н.Г. Ничкало. Кривий Ріг : Видавничий дім, 2011. 439 с.

21. Тернопільська В.І., Чижова Н.В. Мобільність особистості як предмет наукового дослідження. Теоретико-методичні проблеми виховання дітей та учнівської молоді. 2016. № 20. С. 234-243.

22. Тернопольская В.И., Бакулина О.С. Особенности формирования профессиональной компетентности будущих специалистов по налогообложению и таможенному делу. International scientific journal “Progress". 2018. № 1-2. P. 94-97.

23. Santiago P., Tremblay K., Basri E., Arnal E. Tertiary Education for the Knowledge Society. Social Features, Equity, Innovation, Labour Market, Internationalisation. 2008. Vol. 2. P. 243.

24. Umriß pädagogischer Vorlesungen Verfasserang. / Johann Friedrich Herbart. Besorgt von Eva Matthes; Carsten Heinze Ort Darmstadt Verlag Wiss. Buchges., 2003. 168 P.

\section{Information about the authors: Ternopilska V. I.,} Doctor of Pedagogical Sciences, Professor, Professor at the Department of Theory and Technology of Social Work National Pedagogical Dragomanov University 9, Pyrohova str., Kyiv, 01601, Ukraine

Bakulina O. S., Ph. D., Associate Professor at the Department of Entrepreneurship, Finance and Taxation Zhytomyr Branch of the University of State Fiscal Service of Ukraine 96, Pokrovska str., Zhytomyr, 10031, Ukraine 